\title{
Constipation and poor feeding in an infant with botulism
}

\author{
Kevin L. Schwartz MD, John W. Austin PhD, Michelle Science MD
}

$\mathrm{A}$ 5-month-old previously well infant was taken to the emergency department because of parental concerns about constipation and feeding difficulties. She was born at term and had passed meconium within 24 hours. She had been having daily bowel movements, but at the time of assessment she had not had one in 15 days. She was breastfeeding poorly and was drooling more than usual. Her parents also noticed that she was weak in both the upper and lower extremities and was no longer able to roll over. She had no fever, upper respiratory or other gastrointestinal symptoms.

The pregnancy had been unremarkable. The infant was delivered at home with the help of a midwife. Her birth weight was $4.3 \mathrm{~kg}$. She was breastfed exclusively, with no ingestion of solid foods or honey. She had not had any illnesses or need of hospital care. She was not vaccinated because of parental preference. The family was living in a house in a rural area in Canada.

On initial physical examination, the infant appeared well. Her vital signs were normal, and she had no signs of distress. The findings of a systemic examination in the emergency department were normal. There were no signs of gastrointestinal obstruction, and the rectal examination showed no abnormalities. Constipation was diagnosed, and the infant was discharged home.

After 5 days of persistent constipation, weakness and poor muscle tone, and 3 separate outpatient medical assessments, the girl was referred to the emergency department and admitted to hospital for monitoring and further investigation. Laboratory tests showed a normal complete blood count, electrolyte levels and metabolic test results, including normal lactate, ammonia and blood gas levels. Lumbar puncture revealed a leukocyte count of $3 \times 10^{6} / \mathrm{L}$, an erythrocyte count of $1 \times 10^{6} / \mathrm{L}$, a protein level of $0.2 \mathrm{~g} / \mathrm{L}$ and a glucose level of $2.7 \mathrm{mmol} / \mathrm{L}$, all within normal limits. Cultures of blood, urine and cerebral spinal fluid were negative for bacteria. Magnetic resonance imaging of the brain showed no abnormalities.
Because of the presence of constipation together with neurologic findings of peripheral hypotonia and bulbar involvement, as suggested by the feeding difficulties and excessive drooling, a diagnosis of infant botulism was considered by the admitting physician. A fecal sample was sent to Health Canada's Botulism Reference Service for Canada. It tested positive for botulinum neurotoxin type A. Polymerase chain reaction assay was positive for the type A neurotoxin gene, and an enrichment culture yielded Clostridium botulinum type A.

Given the patient's clinical presentation and the detection of toxin in the fecal sample, infant botulism was diagnosed on day 4 of admission. The patient breastfed throughout her hospital stay, requiring only 48 hours of feeding through a nasogastric tube. She had no signs of respiratory compromise and gradually showed improvement in the power in her limbs. Given her clinical improvement at the time of diagnosis, her prolonged history and mild presentation, she was not given antitoxin. It was decided to observe her in hospital and consider antitoxin if she required antibiotic therapy for a secondary bacterial infection.

On discharge home after 7 days, the patient had only mild weakness, was feeding well and had no further excessive drooling. Over the next few weeks, she made a complete recovery to baseline neurologic and developmental status. Culture of honey products from her home were negative for $C$. botulinum; no other household products were tested.
Competing interests: None declared.

This article has been peer reviewed.

Correspondence to: Kevin Schwartz, kevin.schwartz@sickkids.ca

CMAJ 2012. DOI:10.1503 /cmaj.120340 


\section{Discussion}

Infant botulism is not common. In Canada, 38 cases were reported between 1979 and 2010, for an incidence of 1.2 cases per year. ${ }^{1}$ In the United States, about 100 cases are reported annually. ${ }^{2}$ However, these numbers may be underestimates because of misdiagnosis.

Botulism comes in several forms. Details of their incidence, pathophysiology and diagnosis are outlined in Table $1 .^{2-6}$ All forms are caused by botulinum toxin, of which there are 7 serotypes. Type A and B are responsible for most cases of infant botulism, with type $\mathrm{F}$ causing a few cases and type $\mathrm{E}$ being implicated in 1 reported case. Botulinum toxin exerts its effect by binding to the presynaptic cholinergic receptors and irreversibly preventing the release of acetylcholine. The toxin does not cross the blood-brain barrier, which explains the preservation of the central nervous system and cognitive functioning. We will focus on infant botulism in the remainder of this article.

\section{What are the risk factors?}

Most cases of infant botulism in North America likely result from exposure to spores in dust and soil. Exposure to spores in honey is also possible, but this is relatively rare, occurring in only $5 \%$ of North American cases. ${ }^{8}$
Although the spores are not normally infectious to healthy children and adults, they can cause disease in infants under 12 months of age for reasons that are not completely understood. The predominant theory suggests a lack of competitive flora in the gastrointestinal tract, which has been shown in mouse models. ${ }^{9}$

\section{Honey}

Spores of C. botulinum have been isolated from pasteurized and unpasteurized honey. Pasteurization will prolong the shelf life of honey, but the temperature achieved is not sufficient to inactivate the spores, which can withstand temperatures of $100^{\circ} \mathrm{C}$ for hours. Consumption of honey remains an important preventable risk factor despite it being associated with relatively few cases of infant botulism in North America. Caregivers should avoid giving honey to infants under 12 months old.

\section{Other risk factors}

Other risk factors for infant botulism have been suggested from small cohort studies and retrospective case series, as summarized by Domingo and colleagues. ${ }^{4}$ These include prolonged breastfeeding, introduction of solid foods, white race, two-parent families and presence of medical insurance. However, these risk factors remain an area of controversy.

Table 1: Characteristics of different forms of botulism

\begin{tabular}{|c|c|c|c|c|c|}
\hline $\begin{array}{l}\text { Type of } \\
\text { botulism }\end{array}$ & Incidence & Risk factors & $\begin{array}{l}\text { Incubation } \\
\text { period }\end{array}$ & Laboratory diagnosis & Pathophysiology \\
\hline Infant ${ }^{2-4}$ & $\begin{array}{l}\text { Canada: } 1 / y r \\
\text { United States: 100/yr }\end{array}$ & $\begin{array}{l}\text { Age }<12 \mathrm{mo} \text {; exposure to } \\
\text { contaminated dust/soil and } \\
\text { honeyt }\end{array}$ & Unknown & $\begin{array}{l}\text { Toxin or spores in feces } \\
\text { (toxin in serum is rarely } \\
\text { detected but would also } \\
\text { confirm diagnosis) }\end{array}$ & $\begin{array}{l}\text { Ingestion and } \\
\text { subsequent growth } \\
\text { of spores, with toxin } \\
\text { production in } \\
\text { gastrointestinal tract }\end{array}$ \\
\hline Foodborne $e^{2,3}$ & $\begin{array}{l}\text { Canada: } 10 / y r^{*} \\
\text { United States: } 20 / y r^{*}\end{array}$ & $\begin{array}{l}\text { Ingestion of contaminated } \\
\text { food }\end{array}$ & $12-72 \mathrm{~h}$ & $\begin{array}{l}\text { Toxin in serum, feces, gastric } \\
\text { aspirate or implicated food; } \\
\text { or culture of gastric aspirate } \\
\text { or feces and clinical } \\
\text { presentation consistent } \\
\text { with botulism }\end{array}$ & $\begin{array}{l}\text { Ingestion of } \\
\text { preformed toxin }\end{array}$ \\
\hline Wound $^{2,3}$ & $\begin{array}{l}\text { Canada: None } \\
\text { reported } \\
\text { United States: } \sim 30 / y r\end{array}$ & $\begin{array}{l}\text { Injection of illicit drugs; } \\
\text { nasal or sinus lesions due } \\
\text { to chronic cocaine sniffing; } \\
\text { deep wounds }\end{array}$ & $7 d$ & $\begin{array}{l}\text { Toxin in serum; or culture } \\
\text { of tissue from the wound }\end{array}$ & $\begin{array}{l}\text { Germination of } \\
\text { spores in wound, } \\
\text { with toxin } \\
\text { production in vivo }\end{array}$ \\
\hline $\begin{array}{l}\text { Adult } \\
\text { enteric } c^{3,5}\end{array}$ & Canada: 5 reported & $\begin{array}{l}\text { Crohn disease; long-term } \\
\text { antimicrobial therapy }\end{array}$ & Unknown & $\begin{array}{l}\text { Repeated positive culture of } \\
\text { feces, toxin in feces, or both }\end{array}$ & $\begin{array}{l}\text { Similar to infant } \\
\text { botulism }\end{array}$ \\
\hline latrogenic $^{6}$ & Rare & $\begin{array}{l}\text { Overdose of injected } \\
\text { botulinum toxin for medical } \\
\text { or cosmetic purposes }\end{array}$ & Days & Toxin in serum & $\begin{array}{l}\text { Intramuscular } \\
\text { injection of toxin }\end{array}$ \\
\hline Inhalational ${ }^{3}$ & $\begin{array}{l}\text { Very rare (none } \\
\text { reported in Canada) }\end{array}$ & $\begin{array}{l}\text { Laboratory worker or } \\
\text { bioterrorism }\end{array}$ & $12-80 \mathrm{~h}$ & $\begin{array}{l}\text { Toxin detection from nasal } \\
\text { swab (toxin not usually } \\
\text { detected in serum or feces) }\end{array}$ & $\begin{array}{l}\text { Inhalation of } \\
\text { aerosolized toxin }\end{array}$ \\
\hline
\end{tabular}


Some studies have implicated breastfeeding as a risk factor for infant botulism, whereas others have suggested it offers a protective effect. ${ }^{4}$ It has been postulated that any change in intestinal milieu in infants can increase susceptibility to colonization with Clostridium species. Prolonged breastfeeding and the introduction of solid foods can cause such changes, and some case series have identified these as potential risk factors. ${ }^{4}$ Defining risk factors for this rare condition remains a challenge and requires further investigation.

\section{How does infant botulism present?}

Infant botulism affects infants usually between 2 weeks and 12 months of age (median 10 weeks). The clinical spectrum of disease ranges from asymptomatic infection to life-threatening disease. In the classic form, infants present with constipation, followed by poor feeding and lethargy. Subsequently, a subacute deterioration may occur over 4 to 5 days, with symmetric bulbar palsies (i.e., ptosis, ophthalmoplegia, sluggish pupillary responses, poor suck-swallow reflex, expressionless face) and weakness, and occasionally may present as developmental regression. Hypoventilation requiring mehanical ventilation may develop in $60 \%$ of untreated infants who present to hospital. ${ }^{8}$

Other considerations on the differential diagnosis of infant botulism should include, but are not limited to, congenital or transient myasthenia gravis, magnesium or aminoglycoside toxicity, spinal muscular atrophy, Miller-Fisher syndrome (a variant of Guillain-Barré syndrome) and a variety of inherited metabolic disorders. ${ }^{10}$

\section{How is the diagnosis made?}

The presence of constipation and symmetric bulbar palsies, particularly if hypoventilation is present, should prompt the clinician to consider a diagnosis of infant botulism. The diagnosis is supported by electromyographic findings of abnormal incremental responses to repetitive nerve stimulation or short-duration, low-amplitude motor unit potentials. The clinical diagnosis is confirmed by the detection of $C$. botulinum spores or toxin in feces or, rarely, the detection of toxin in serum. An enema can be used to obtain fecal samples, since affected infants are commonly constipated on presentation.

\section{Who should receive botulism immune globulin?}

Any infant with suspected botulism should be admitted to hospital and monitored for complications. A human botulism immune globulin has been developed to replace the equine antitoxin used in adults because of concerns over the use of equine antitoxin, including anaphylaxis, serum sickness and a short half-life of 5 to 7 days.

The human botulism immune globulin was studied in a randomized, double-blind, placebocontrolled trial involving 122 infants with botulism and was found to be efficacious and costeffective. ${ }^{8}$ The average onset of symptoms in the trial was 3 days before admission. Treatment within 72 hours after admission resulted in a decrease in the length of hospital stay by 3.1 weeks, the duration of mechanical ventilation by 2.6 weeks and the total hospital charges per patient by US $\$ 88600$ on average. A smaller benefit was seen if the immune globulin was given between 3 and 7 days after admission. Human botulism immune globulin does not reverse neurologic symptoms already present; rather, it prevents further binding of toxin, thereby limiting further deterioration.

Human botulism immune globulin was not used in our patient because of her prolonged history of symptoms ( 2 weeks), mild presentation and signs of improvement. However, it should be considered for use in any infant suspected of having botulism, within 3 to 7 days after presentation. Use after this period has not been studied but may be indicated if there is clinical deterioration or antibiotic treatment is needed.

Currently, the use of antibiotics specifically to treat infant botulism is not recommended. ${ }^{11}$ Antibiotics may result in lysis of intraluminal C. botulinum, which may result in increased toxin release and worsening neurologic symptoms, as has been shown with aminoglycosides. ${ }^{12}$ When antibiotics are required to treat secondary bacterial infections (e.g., pneumonia), the use of human botulism immune globulin before administration should be considered because it may prevent further neurologic deterioration from toxin release. ${ }^{8}$

Botulism of any form requires admission to hospital because of the high risk of respiratory failure. Aggressive supportive measures, with ventilator support if required, has resulted in dramatic decreases in mortality from about $50 \%$ to $5 \%,{ }^{2}$ and to less than $1 \%$ among infants. ${ }^{8}$

\section{What resources are available for clinicians?}

Health Canada's Botulism Reference Service for Canada, established in Ottawa in 1974, can assist physicians and provincial departments of health when botulism is suspected (www.hc-sc.gc.ca/sr -sr/activ/micro/botulism-eng.php). It examines suspect foods and clinical specimens submitted for analysis and will alert responsible agencies (local, national and international) when commer- 
cial foods are involved. It also maintains reference cultures of $C$. botulinum.

Botulism is a notifiable disease in each province and territory in Canada. Upon suspicion of infant botulism, the responsible physician should contact his or her ministry of health, which can help to arrange for stool samples to be tested and human botulism immune globulin, if indicated, to be shipped from California at a cost.

\section{References}

1. Ontario Ministry of Health and Long-Term Care. Botulism [fact sheet]. Toronto (ON): The Ministry; 2010. Available: www.health .gov.on.ca/en/public/publications/disease/botulism.aspx (accessed 2012 May 10).

2. US Centers for Disease Control and Prevention (CDC). Botulism: general information. Atlanta (GA): CDC; 2010. Available: www.cdc.gov/nczved/divisions/dfbmd/diseases/botulism/ (accessed 2012 May 10).

3. Public Health Agency of Canada. Clostridium botulinum. pathogen safety data sheet - infectious substances 2010. Ottawa (ON): The Agency; 2010. Available: www.phac-aspc.gc.ca/lab-bio /res/psds-ftss/clostridium-eng.php (accessed 2012 May 10).

4. Domingo RM, Haller JS, Gruenthal M. Infant botulism: two recent cases and literature review. J Child Neurol 2008;23:1336-46.

5. Sheppard YD, Middleton D, Whitfield Y, et al. Intestinal toxemia botulism in three adults, Ontario, Canada, 2006-2008. Emerg Infect Dis 2012;18:1-6.
6. Chertow DS, Tan ET, Maslanka SE, et al. Botulism in four adults following cosmetic injections with an unlicensed, highly concentrated botulinum preparation. JAMA 2006;296:2476-9.

7. Lúquez C, Dykes JK, Yu PA, et al. First report worldwide of an infant botulism case due to Clostridium botulinum type E. J Clin Microbiol 2010;48:326-8.

8. Arnon SS, Schechter R, Maslanka SE, et al. Human botulism immune globulin for the treatment of infant botulism. $N$ Engl J Med 2006;354:462-71.

9. Wells CL, Sugiyama H, Bland SE. Resistance of mice with limited intestinal flora to enteric colonization by Clostridium botulinum. J Infect Dis 1982;146:791-6.

10. Francisco AMO, Arnon SS. Clinical mimics of infant botulism. Pediatrics 2007;119:826-8.

11. American Academy of Pediatrics. Botulism and infant botulism In: Pickering LK, Baker CJ, Kimberlin DW, et al., editors. Red book: 2009 report of the Committee on Infectious Diseases. 28th ed. Elk Grove Village (IL): The Academy; 2009. p. 259-62.

12. L'Hommedieu C, Stough R, Brown L, et al. Potentiation of neuromuscular weakness in infant botulism by aminoglycosides. J Pediatr 1979;95:1065-70.

Affiliations: From the Division of Infectious Diseases (Schwartz, Science), The Hospital for Sick Children, Toronto, Ont.; the Bureau of Microbial Hazards (Austin), Health Canada, Ottawa, Ont.; and the Department of Clinical Epidemiology and Biostatistics (Science), McMaster University, Hamilton, Ont.

Contributors: All of the authors were involved in drafting the article, revised it critically and approved the final version submitted for publication. 